\title{
Acid atmospheric deposition in a forested mountain catchment
}

\author{
Josef Křeček ${ }^{(1)}$, \\ Ladislav Palán (1), \\ Evžen Stuchlík (2)
}

\begin{abstract}
Acid atmospheric deposition is harmful to both forest and aquatic ecosystems. In mountain catchments, acidification also leads to difficulties in water resource management. In 2010-2012, acid atmospheric deposition was analysed in a small forest catchment located in the upper plain of the Jizera Mountains (Czech Republic). Patch observations included monitoring of the canopy interception in two mature stands of Norway spruce (Picea abies) at elevations of 745 and 975 metres a.s.l., and twelve passive fog collectors situated along an elevation gradient between 862 and 994 metres a.s.l. In the studied area, fog (and low cloud) precipitation starts to affect the interception loss of the spruce canopy at elevations above $\mathbf{7 0 0}$ metres. However, fog drip was found to also rise with the canopy area. At the catchment scale, methods of spatial interpolation (ArcGIS 10.2) were used to approximate the aerial atmospheric deposition of water and acidic substances (sulphate, nitrate and ammonia). In the watersheds of two adjacent drinking water reservoirs, Josefưv Důl and Souš, the mean annual fog drip from the canopy was between 88 and $106 \mathrm{~mm}$ (i.e., $7-8 \%$ of the mean annual gross precipitation, or $10-12 \%$ of the mean annual runoff). Simultaneously, this load also deposited $658 \mathrm{~kg} \mathrm{~km}^{-2}$ of sulphur and $216 \mathrm{~kg} \mathrm{~km}^{-2}$ of nitrogen (i.e., $55 \%$ and $48 \%$ of the "open field" bulk amounts). Therefore, in headwater catchments stressed by acidification, the additional precipitation (measured under the canopy) can increase the water yield, but can also contribute to a decline in water quality, particularly in environments of low buffering capacity.
\end{abstract}

\section{Keywords: Mountain Watershed, Spruce Forests, Acid Atmospheric Deposition, Water Resources Recharge}

\begin{abstract}
Introduction
Acid rain directly affects the chemical and $\mathrm{pH}$ balances of surface and ground waters in headwater regions of central Europe (Holen et al. 2013). Low pH values cause the mobilisation of toxic aluminium, which reduces the biota in water courses and reservoirs. Fog and cloud waters have been recognised as important carriers for the deposition of water-borne pollutants in high elevation forests (Kroll \& Winkler 1989, Whitman 2000, Wrzesinsky \& Klemm 2000). The process of fog condensation on vegetation foliage and dripping to soil surfaces can significantly affect the water balance in mountain watersheds (Vogelmann 1973, Krečmer et al. 1979, Ingwersen 1985, Lovett \& Reiners 1986, Dawson 1998). Recently, fog collection technologies (simple

devices based on erected nets facing oncoming winds and trapping water particles in the air) have been developed in many parts of the world to modify the water cycle and to support local water supplies (Ruiz 2005). Fog has also been viewed as an important source of moisture in coastal ecosystems (Dawson 1998); however, effective fog/cloud water trapping by vegetation has been mainly reported in cloud forests (Vogelmann 1973, Holder 2003, Hildebrandt \& Eltahir 2008). In general, higher elevation forests show relatively significant additional water yields due to the occurrence of fog (Ingwersen 1985, Walmsley et al. 1996, Igawa et al. 2002), and Holder (2003) has called the conservation of high elevation forests an important tool for water supply engineering.
\end{abstract}

(1) Department of Hydraulics and Hydrology, Czech Technical University in Prague, Thákurova 7, CZ-166 29 Prague 6 (Czech Republic); (2) Institute of Hydrobiology, Biology Centre CAS, Na Sádkách 7, CZ-37005 České Budějovice (Czech Republic)

@ Ladislav Palán (ladislav.palan@fsv.cvut.cz)

Received: Dec 16, 2016 - Accepted: May 08, 2017

Citation: Křeček J, Palán L, Stuchlík E (2017). Acid atmospheric deposition in a forested mountain catchment. iForest 10: 680-686. - doi: 10.3832/ifor2319-010 [online 2017-07-17]

Communicated by: Elena Paoletti
Considering forests in Central Europe, Brechtel (1989) reported an elevation of $700 \mathrm{~m}$ as the threshold of significant fog precipitation. Upland watersheds above $700 \mathrm{~m}$ are currently covered mainly by coniferous forests (Andersson 2005). Fog drip in short vegetation types (like grass) has been found to be much smaller than in forests, with deposition intensities of 0.018 -0.02 mm per hour in grasslands compared with $0.02-0.4 \mathrm{~mm}$ per hour in coniferous forests (Lovett \& Reiners 1986, Hildebrandt \& Eltahir 2008). In addition to canopy structure, however, a number of variables such as wind speed, liquid water content and droplet sizes influence the deposition of fog/cloud precipitation (Whitman 2000). In regions affected by polluted air (particularly emissions of sulphur and nitrogen) and by consequent acid atmospheric deposition, processes trapping fog from the atmosphere can intensify the decline of water environment and water resources (Verhoeven et al. 1987, Delleur 1989, Schemenauer et al. 1995, Igawa et al. 2002, Schöpp et al. 2003, Kim et al. 2006, Kreček \& Hořická 2006). Therefore, land use and watershed management practices might influence the volumes and chemistry of cloud/fog precipitation as well as the recharge, quantity and quality of water resources (Kim et al. 2006, Kreček \& Hořická 2010). Increasing inputs of acid substances from fog precipitation may result in lower 


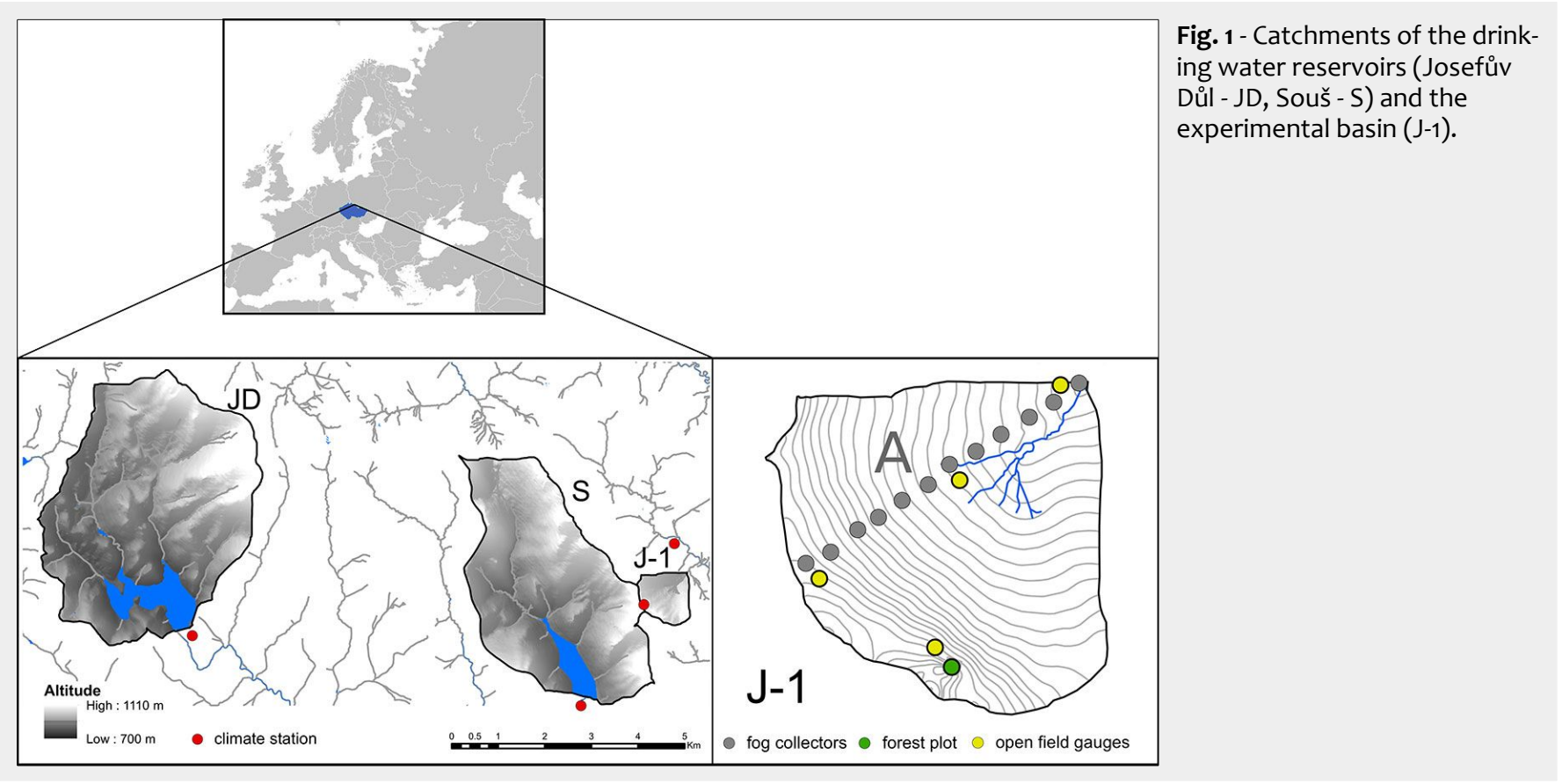

$\mathrm{pH}$, reduced contents of calcium and magnesium (and water hardness), and the mobilisation of aluminium in water environments (Merilehto et al. 1988, Mosello et al. 1995, Kreček \& Hořická 2006). pH is one of the most important operational water quality parameters, with national guidelines for drinking water quality often suggesting an optimum $\mathrm{pH}$ in the range 6.5 to 8.5 (WHO 2004). Without air pollution and subsequent acid rain, most lakes and streams would have a $\mathrm{pH}$ level close to 6.5 (Merilehto et al. 1988). However, in the headwaters of the European "Black Triangle", in the late 1980 s water $\mathrm{pH}$ rose to 4-5 and concentrations of aluminium increased to 1-2 mg per litre (Kreček \& Hořická 2010). The limit of aluminium in drinking water is $0.1 \mathrm{mg}$ per litre for large treatment facilities and $0.2 \mathrm{mg}$ per litre for small facilities (WHO 2004). Therefore, in some water treatment plants, the increased acidity of raw water necessitated several additional investments (Kreček \& Palán 2015). The aim of this study was to analyse the genesis of acid atmospheric deposition in forested headwater catchments of the Jizera Mountains (Czech Republic) with special attention on the role of fog/low cloud events, elevation and vegetation canopy.

Tab. 1 - Characteristics of the investigated plots 1 and $2(30 \times 30 \mathrm{~m})$.

\begin{tabular}{lcc}
\hline \multirow{2}{*}{ Parameter } & \multicolumn{2}{c}{ Plots } \\
\cline { 2 - 3 } & $\mathbf{1}$ & $\mathbf{2}$ \\
\hline Elevation $(\mathrm{m})$ & 745 & 975 \\
Tree species & Picea abies & Picea abies \\
Age (years) & $80-100$ & $80-100$ \\
Number of trees & 54 & 68 \\
Mean height $(\mathrm{m})$ & 24 & 23 \\
Horizontal canopy density $\left(\mathrm{m}^{2} \mathrm{~m}^{-2}\right)$ & 0.92 & 0.78 \\
Leaf area index $\left(\mathrm{m}^{2} \mathrm{~m}^{-2}\right)$ & 7.3 & 6.7 \\
\hline
\end{tabular}

\section{Precipitation analyses}

We analysed precipitation using the water balance method under a canopy proposed by Lovett (1988) as the most appropriate approach for measuring fog and cloud water deposition in ecological studies. During the period 2011-2012, precipitation (including fog-drip) under the canopy of two mature spruce stands (plots 1 and 2, at elevations of 745 and 975 metres a.s.l. Fig. 1) were collected by modified Hellmann rain gauges (area of $200 \mathrm{~cm}^{2}$, plastic collectors with a shield against bird contamination). Sets of ten gauges were randomly installed in plots of $30 \times 30$ metres according to forest characteristics (Tab. 1) and the method proposed by Krečmer \& Páv (1982). The amount of fog drip was estimated by comparing the volumes of water collected by these sets of ten gauges with a single rain gauge installed in adjacent forest openings (i.e., "bulk", located 30 to 50 metres away from the forest edge). According to Krečmer et al. (1979), in spruce stands the stemflow of rainwater can be considered to be negligible. To test this assumption at our stands, stemflow in the investigated plots was collected by plastic tubing installed around the circumference of four selected trunks. Collected volumes of water were recorded at monthly intervals; the interception loss of the canopy (I) was calculated as (eqn. 1):

$$
I=\sum_{i=1}^{n} \frac{1}{m} P-\left(\sum_{i=1}^{n} \frac{1}{m} P_{t}+\sum_{i=1}^{n} \frac{1}{m} P_{s}\right)
$$

where $P$ is the open field (gross) precipitation $(\mathrm{mm}), P_{\mathrm{t}}$ is the throughfall under the canopy $(\mathrm{mm}), P_{\mathrm{s}}$ is the stemflow, $\mathrm{n}$ is the number of months, $m$ is the number of seasons.

To identify the effect of elevation on potential fog drip, twelve passive fog collectors were installed in vertical transect $A$ of 
the Jizerka experimental catchment ( $\mathrm{J}-1$, area of $1 \mathrm{~km}^{2}$, elevation gradient from 862 to 994 metres - Fig. 1), where mature spruce stands were harvested by clear-cutting. For each collector, the fog drip was generated using 400 metres of Teflon line (diameter of 0.25 millimetres, i.e., surface area index $=5$ ) installed at a height of 1.7 metres above the ground, and collected in one-litre sample bottles at monthly intervals. Sample bottles were protected against direct rainfall access by a widebrimmed cover that overlapped the fog collector at an angle of $34^{\circ}$.

The collected water samples (fog drip, throughfall and stemflow) were analysed by standard techniques in the Hydrobiological Laboratory Velký Pálenec (Charles University in Prague), including $\mathrm{pH}$, conductivity, and contents of elements related to acid atmospheric deposition - sulphur ( $\mathrm{S}$ $\left.\mathrm{SO}_{4}\right)$ and nitrogen $\left(\mathrm{N}-\mathrm{NO}_{3}, \mathrm{~N}-\mathrm{NH}_{4}\right)$. Concentrations of $\mathrm{NO}_{3}^{-}$and $\mathrm{SO}_{4}{ }^{2-}$ were determined by ion chromatography, and $\mathrm{NH}_{4}{ }^{+}$by the rubazoic acid method (Kopáček \& Procházková 1993). Although bacterial activity may alter the chemical composition of water after collection (especially nitrogen - Golterman 1969), in our case the relatively cold mountain climate (subarctic region), relatively high concentrations of nitrogen, and low values of $\mathrm{pH}$ and dissolved organic carbon likely limited bacterial activity (Cape et al. 2001). The potential growth of algae was reduced by using dark sampling bottles and keeping samples in the dark during transport.

\section{Precipitation deposition in watersheds}

Findings worldwide (Krečmer et al. 1979, Brechtel 1989, Dawson 1998) have shown that in mountain watersheds, fog drip deposition increases with elevation and canopy density. Therefore, the hypsometric method with spatial interpolation (using ArcGIS 10.2) was employed to approximate the spatial atmospheric deposition of fog water $\left(\mathrm{P}_{\mathrm{fd}}\right)$, sulphur $\left(\mathrm{S}-\mathrm{SO}_{4}\right)$ and nitrogen $\left(\mathrm{N}-\mathrm{NO}_{4}, \mathrm{~N}-\mathrm{NH}_{4}\right)$ in two watersheds containing drinking water reservoirs in the Jizera Mountains, Josefưv Důl and Souš (Fig. 1). To identify seasonal relationships between fog drip and elevation, data from the fog collectors was analysed separately for the summer (May-October) and winter (November-April) seasons. The occurrence of fog was also recorded at four nearby climate stations: Josefův Důl (elevation of $745 \mathrm{~m}$ a.s.l.), Souš (772 $\mathrm{m}$ ), and at the highest and lowest points in the Jizerka experimental basin (980 and $850 \mathrm{~m}$ - Fig. 1).

Several authors (Krečmer et al. 1979, Lovett \& Reiners 1986, Weathers et al. 1995) have observed higher fog drip at the edges of forest stands, sometimes exceeding the fog deposition in a nearby stand by 3 to 15 times. However, in fragmented forest stands such as those in the Jizera Mts. Krečmer et al. (1979) found increases of only up to $10 \%$ in border areas $10-20$ metres wide. We therefore neglected the edge effect in this study.

The vegetation canopy was analysed by satellite (Landsat imagery, resolution of 30 $\times 30 \mathrm{~m})$ and detailed ground investigations (Kreček \& Krčmář 2015). Then, the canopy surface was categorised into groups of herbaceous plants and forest stands, and their delineation in watersheds was performed. In the Jizerka experimental catchment, ground-based canopy analyses were carried out for twenty selected plots $(30 \times$ $30 \mathrm{~m}$ ). Twelve of these were instrumented by passive fog collectors (along the harvested transect $A$ - Fig. 1) and two by sets of ten rain gauges installed under the canopy. The forestry characteristics (age, stocking, horizontal canopy density) were estimated by a standard inventory (Kreček \& Hořická 2010). The capacity for fog deposition was approximated by the fog-drip coefficient $F_{c}$ according to the canopy surface estimates (Krečmer et al. 1979). The value of the coefficient $F_{c}$ ranges from o to 1. Equation 2 was used to calculate the seasonal volume of fog precipitation for a specified canopy, elevation and season. The relation is based on a simple linear hypsometric relation between altitude and the precipitation volume (eqn. 2).

$$
P_{f d}=0.001 \cdot\left(a \cdot E+a_{0}\right) A_{e r}^{-1} \cdot F_{c}
$$

where $P_{\mathrm{fd}}$ is the seasonal amount of fog drip (mm), $a$ and $a_{0}$ are coefficients of the hypsometric relation derived for the individual season, $E$ is the elevation ( $m), A_{\mathrm{er}}$ is the effective receptor area $\left(\mathrm{m}^{2}\right)$, and $F_{\mathrm{c}}$ is the fog drip coefficient.

Similarly, the hypsometric method was used to assess the water quality of the deposited fog. Concentrations of the acidic substances (sulphate, nitrate and ammonia) from the fog collectors and rain gauges were used to estimate seasonal amounts of deposited elements (eqn. 3):

$$
m=\left(b \cdot E+b_{0}\right) \cdot A_{e r}^{-1} \cdot F_{c}
$$

where $\mathrm{m}$ is the seasonal amount of deposited elements $\left(\mathrm{kg} \mathrm{km}^{-2}\right), b$ and $b_{\circ}$ are coefficients of the hypsometric relation derived for individual season and element, $E$ is the elevation (m), $A_{\text {er }}$ is the effective receptor area $\left(\mathrm{m}^{2}\right)$, and $F_{\mathrm{c}}$ is the fog drip coefficient.

Standard descriptive statistics (including mean, median, maximum and minimum values, standard deviation - SD, standard

Tab. 2 - The correlation matrix of elevation $E(m)$, sampled volume of fog drip $V(\mathrm{ml})$,

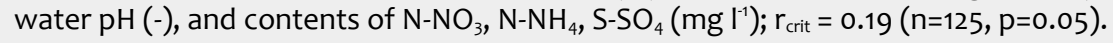

\begin{tabular}{lllllll}
\hline- & $\mathbf{E}$ & $\mathbf{V}$ & $\mathrm{pH}$ & $\mathrm{N}-\mathrm{NO}_{3}$ & $\mathrm{~N}-\mathrm{NH}_{4}$ & $\mathrm{~S}^{-\mathrm{SO}_{4}}$ \\
\hline $\mathrm{E}$ & 1 & 0.21 & -0.20 & 0.03 & 0.03 & -0.05 \\
$\mathrm{~V}$ & 0.21 & 1 & -0.72 & 0.39 & 0.02 & 0.07 \\
$\mathrm{pH}$ & -0.20 & -0.72 & 1 & -0.50 & -0.29 & -0.23 \\
$\mathrm{~N}-\mathrm{NO}_{3}$ & 0.03 & 0.39 & -0.50 & 1 & 0.08 & 0.13 \\
$\mathrm{~N}^{-\mathrm{NH}_{4}}$ & 0.03 & 0.02 & -0.29 & 0.08 & 1 & 0.82 \\
$\mathrm{~S}_{4} \mathrm{SO}_{4}$ & -0.05 & 0.07 & -0.23 & 0.13 & 0.82 & 1 \\
\hline
\end{tabular}
confidence limits), normality test, and oneway ANOVA were used to analyse the data and to identify relationships between the groups of data (Motulsky \& Searle 1998). The paired $t$-test comparing means of two groups of a variable was used to test differences between groups, and the correlation was tested by the Pearson's coefficient.

\section{Results and discussion}

\section{Effects of elevation and canopy}

The correlation matrix of elevation $\mathrm{E}(\mathrm{m})$, sampled volume of fog drip $\mathrm{V}(\mathrm{ml})$, water $\mathrm{pH}$, and contents of $\mathrm{N}-\mathrm{NO}_{3}, \mathrm{~N}-\mathrm{NH}_{4}, \mathrm{~S}^{-\mathrm{SO}_{4}}$ ( $\mathrm{mg} \mathrm{l}^{-1}$ ) is presented in Tab. 2. Though passive string collectors are limited in their ability to collect cloud/fog water, and their efficiencies depend on the droplet spectra and wind speed (Schell et al. 1992, Avila et al. 2001), these data allow the effects of elevation to be assessed. It is evident that the groups of data are inter-correlated. With rising elevation, there was a significant increase of fog drip, followed by decreasing water $\mathrm{pH}$. Contents of acidic substances $\left(\mathrm{N}-\mathrm{NO}_{3}, \mathrm{~N}-\mathrm{NH}_{4}, \mathrm{~S}-\mathrm{SO}_{4}\right)$ were not well correlated with elevation, but in higher altitudes their deposition did increase with increasing volumes of precipitated water. There was a linear relationship between mean monthly fog drip and elevation in both summer and winter seasons $0.98, r_{\text {crit }}=0.73(n=5, a=0.1)$, a slope significantly different from zero $(P=0.0082$ and 0.0033$)$, and a non-significant departure from linearity $\left(F=39.3\right.$ and $73.75>F_{\text {crit }}$ = 9.78). During the winter season (November-April), the load of fog precipitation exceeded the summer fog drip (May-October) by $23-50 \%$. October), the observed canopy storage capacity was $2.3 \mathrm{~mm}$. For the seasonal rainfall of $683 \mathrm{~mm}$ (Tab. 3) and approx. 100 rainy days saturating the storage capacity, the total interception loss of rainwater by the spruce canopy could be estimated at about $230 \mathrm{~mm}$. Therefore, in plot 2 the interception losses not affected by the fog drip could reach $34 \%$ of the gross precipitation. Similarly, in a dense mature plantation of Norway spruce (canopy density $0.8-0.9$ ) not affected by additional precipitation from fog or low clouds, Krečmer et al. (1979) reported $37 \%$ interception. The vol- error of mean - SEM, upper and lower 95\% with correlation coefficients $r=0.93$ and

In plot 2 during the warm season (May- 
Tab. 3 - Rainfall and fog-drip sampled in the plots 1 and 2, May-October, 2011- 2012.

\begin{tabular}{|c|c|c|c|c|c|c|c|c|}
\hline \multirow{2}{*}{ Plot } & \multirow{2}{*}{$\begin{array}{l}\text { Precipi- } \\
\text { tation }\end{array}$} & \multirow{2}{*}{$\begin{array}{c}\text { Amount } \\
(\mathrm{mm})\end{array}$} & \multicolumn{2}{|l|}{$\mathrm{pH}(-)$} & \multicolumn{2}{|c|}{$\mathrm{S}-\mathrm{SO}_{4}\left(\mathrm{mg} \mathrm{l}^{-1}\right)$} & \multicolumn{2}{|c|}{$\mathrm{N}-\mathrm{NO}_{3}\left(\mathrm{mg} \mathrm{l}^{-1}\right)$} \\
\hline & & & mean & SD & mean & SD & mean & SD \\
\hline \multirow[t]{2}{*}{1} & Rainfall & 630 & 5.1 & 0.15 & 0.40 & 0.05 & 0.20 & 0.04 \\
\hline & Fog drip & 27 & 4.1 & 0.9 & 4.60 & 0.8 & 1.92 & 0.69 \\
\hline \multirow[t]{2}{*}{2} & Rainfall & 683 & 4.8 & 0.11 & 0.43 & 0.04 & 0.22 & 0.14 \\
\hline & Fog drip & 120 & 3.8 & 1.1 & 7.70 & 1.3 & 3.21 & 1.20 \\
\hline
\end{tabular}

Tab. 4 - Fog drip coefficient $F_{c}$.

\begin{tabular}{clcc}
\hline $\begin{array}{c}\text { Stand } \\
\text { category }\end{array}$ & Age classes & $\begin{array}{c}\text { Horizontal } \\
\text { canopy density }\end{array}$ & $\begin{array}{c}\text { Fog-drip } \\
\text { coefficient } \text { F }_{\mathrm{c}}\end{array}$ \\
\hline 1 & Mature stand & $>0.8$ & 1 \\
2 & Mature stand & $0.65-0.8$ & 0.92 \\
3 & Middle age stand & $0.25-0.65$ & 0.33 \\
4 & Young stand, grass & $<0.25$ & 0.18 \\
\hline
\end{tabular}

ume of stemflow was found to be negligible, which is consistent with the findings of Krečmer at al. (1979) and Lovett \& Reiners (1986). One possible explanations include the centrifugal structure of the spruce canopy and rough stem-bark.

The observed mean interception loss in the summer season (May-October) was $196 \mathrm{~mm}$ (31\% of the gross precipitation) for plot 1 , and $112 \mathrm{~mm}(16 \%)$ for plot 2 . These differences in the interception loss between the two spruce stands could be explained simply by the deposition of fog droplets: 37 and $120 \mathrm{~mm}$ per season (i.e., 0.2 and $0.7 \mathrm{~mm}$ daily).

In the Jizerka experimental catchment (plot 2), the content of sulphur and nitrogen were analysed separately for rain and fog water (Tab. 3). The passive fog drip collectors at different elevations showed in- creasing concentrations of sulphur and nitrogen with increasing elevation. In comparison with rainfall the collected fog precipitation had lower $\mathrm{pH}$, likely because of the genesis of fog droplets in an atmosphere polluted by emissions of sulphur and nitrogen. Verhoeven et al. (1987) reported higher acidity in fog versus rain in the Fichtelgebirge Mountains (Bavaria, Germany) due to an excess of strong mineral acids by anthropogenic emissions into the atmosphere.

At transect A (899-975 $\mathrm{m}$ a.s.l.) during the period 2010-2012, the average annual value of $\mathrm{pH}$ varied with elevation from 3.6 to 4.2 , and the average annual concentration values $\left(\mathrm{mg} \mathrm{l}^{-1}\right)$ of S-SO ${ }_{4}, \mathrm{~N}-\mathrm{NO}_{3}$, and N-NH $\mathrm{N}_{4}$ varied with elevation from 7.7 to 7.9 , from 2.2 to 2.7 , and from 6.2 to 7.2 , respectively. These data correspond to the results of
Pahl et al. (1997), who reported higher amounts of dissolved chemicals (e.g., $\mathrm{SO}_{4}$ ) at greater distances above the cloud base.

In the watersheds of the drinking water reservoirs (Josefův Důl and Souš - Fig. 1), the estimates of the fog-drip coefficient $F_{c}$ was consistent with standard forestry mapping (age classes and horizontal canopy density) for existing spruce plantations. As shown in Tab. 4, values of the $F_{c}$ coefficient reflected the efficiency of the spruce canopy to collect fog droplets with a maximum $\left(F_{c}=1\right)$ in a close mature stand, and decreasing with opening of the canopy.

On the other hand, fog deposition depends on the frequency that fog occurs. The meteorological observation of fog events at elevations of 745, 772, 850 and $980 \mathrm{~m}$ a.s.l. (Fig. 1) showed a statistically significant relation between the number of foggy days and elevation (correlation coefficient $r=0.99, r_{\text {crit }}=0.95, n=4, \alpha=0.05-$ eqn. 4).

$$
D_{f}=0.2178 \cdot E-153.76
$$

where $D$ is the number of foggy days in the summer (days), and $E$ is the elevation ( $m$ ).

In the winter, the number of foggy days exceeded summer values by $60 \%$, corresponding to Tolasz \& Baštýřová (2007). During temperatures below zero, the deposition of fog droplets falls to almost onethird of the potential, according to Lovett \& Reiners (1986).

\section{Watershed deposition}

The observed and approximated loads of fog water and acidic substances were used for deriving the coefficients in the hypsometrically based regression of eqn. 2 and eqn. 3 using the effective receptor area of

Fig. 2 - Mean annual fog drip in the investigated watersheds (2011-2012).

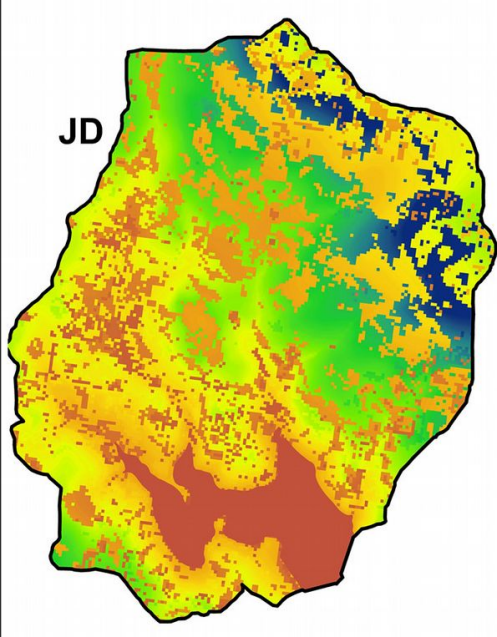

$500 \quad 1000$
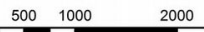

3000 4000

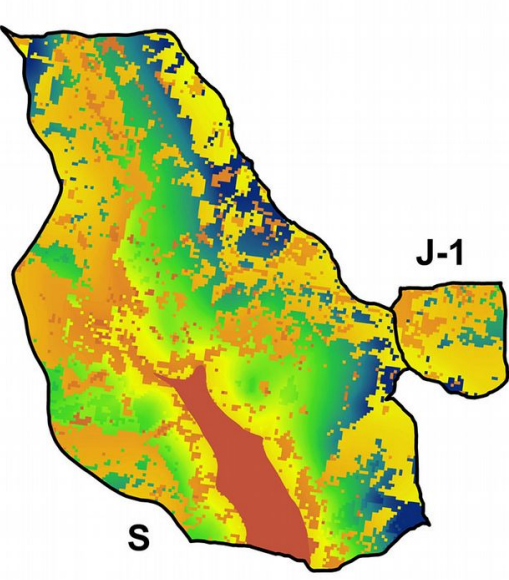

FOG DRIP [mm.year ]
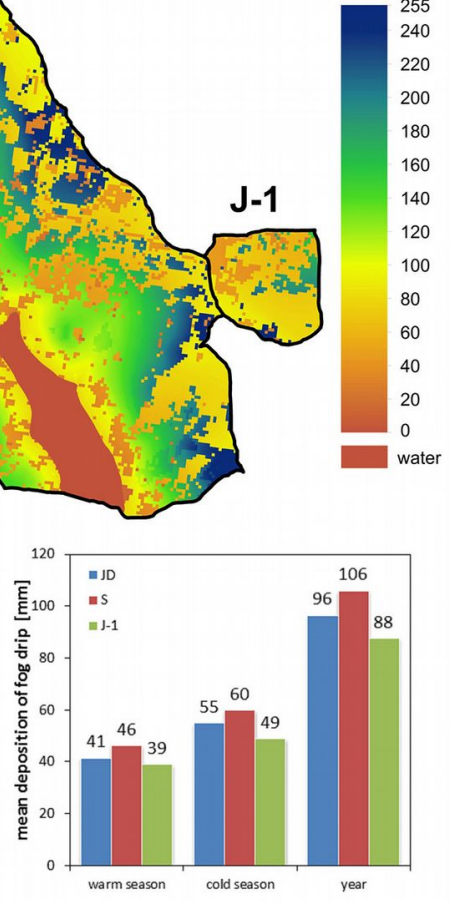
Fig. 3 - Mean annual load of sulphur by fog drip (2011-2012).

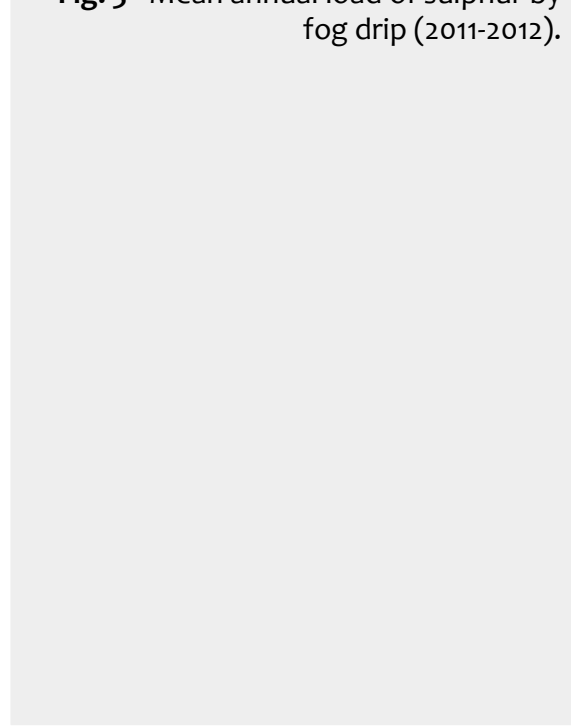

the fog collector $A_{e r}=0.022 \mathrm{~m}^{2}$ and the fog drip coefficient $F_{c}$ depending on the vegetation cover. All relations (Tab. S1, Tab. S2, and Tab. S3 in Supplementary material) were statistically significant, with correlation coefficients varying in absolute value from 0.87 to $0.98\left(r_{\text {crit }}=0.8114, n=6, a=\right.$ 0.05 ), slope different from zero ( $P$ from 0.01 to 0.0015$)$, and a non-significant departure from linearity ( $F$ from 17.34 to 66.66, $F_{\text {crit }}=7.39$ ).

In the catchments of Jizerka (J-1), Josefüv Důl (JD) and Souš (S), approximations of the data using eqn. 2 and eqn. 3 allowed to determinate the spatial distribution of values within catchments respecting local conditions such as the altitude and vegetation cover, resulting in spatial maps of the mean annual load of fog water (Fig. 2), sulphur (Fig. 3) and nitrogen (Fig. 4), and mean annual $\mathrm{pH}$ of fog water (Fig. 5).

The annual load of fog water varied from $7 \%$ to $8 \%$ of the mean annual gross precipitation $(1324 \mathrm{~mm}$, estimated by the hypsometric interpolation of the standard point

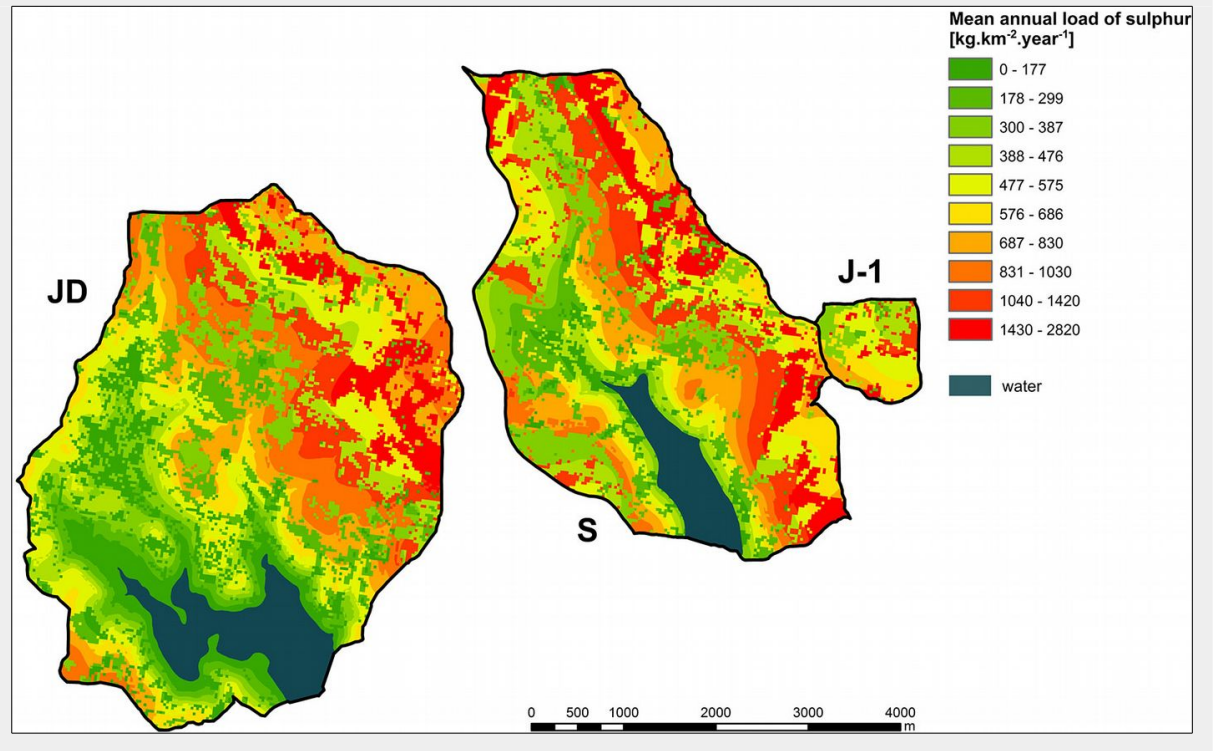

rain gauges). Therefore, the input of fog precipitation in the annual water budget increased the water yield from $10 \%$ to $12 \%$ (by $867 \mathrm{~mm}$ mean annual runoff). On the other hand, the mean annual loads of sulphate and nitrate from fog deposition were 1975 and $1080 \mathrm{~kg} \mathrm{~km}^{-2}$ in the watersheds of Josefův Důl and Souš, i.e., $55 \%$ and $48 \%$ of the amounts of sulphur and nitrogen, respectively, registered in the bulk. Likewise, in the Fichtelberg Mountains (Bavaria, Germany), Wrzesinsky \& Klemm (2000) reported a significant role of fog precipitation in the water balance of forest stands at elevations above $800 \mathrm{~m}$ a.s.l. At a comparable elevation in the White Mountains (New York, USA), Miller et al. (1993) reported that cloud deposition contributed $32 \%$ and $37 \%$ of the total atmospheric load of nitrogen and sulphur.

The spatial maps can also be used to indicate locations in the investigated watersheds vulnerable to higher inputs of fog water, which may in turn affect the trees and water quality within the watersheds.
Generally, based on the spatial distribution of $\mathrm{pH}$, nitrogen and sulphur, the higher altitudes of catchments are at higher risk, especially in combination with the occurrence of a mature coniferous forest. From the spatial distribution of the vegetation cover, it was possible to estimate the total inputs of fog water, sulphur and nitrogen, as well as water $\mathrm{pH}$ into the catchments, providing us with important information on the acidification of water courses and reservoirs in the water supply catchments Josefův Důl and Souš (Fig. 3, Fig. 4, Fig. 5). Because of the very low buffering capacity of the soil and bedrock in these catchments, these acid atmospheric loads directly affect the quality of surface waters (Kreček \& Hořická 2006), and may require investments in water treatment (Kreček \& Palán 2015). Those investments could be reduced, however, using forest management practices that respect conditions for the formation of fog precipitation and its negative role in mountain catchments stressed by acidification.

Fig. 4 - Mean annual load of nitrogen by fog drip (2011-2012).

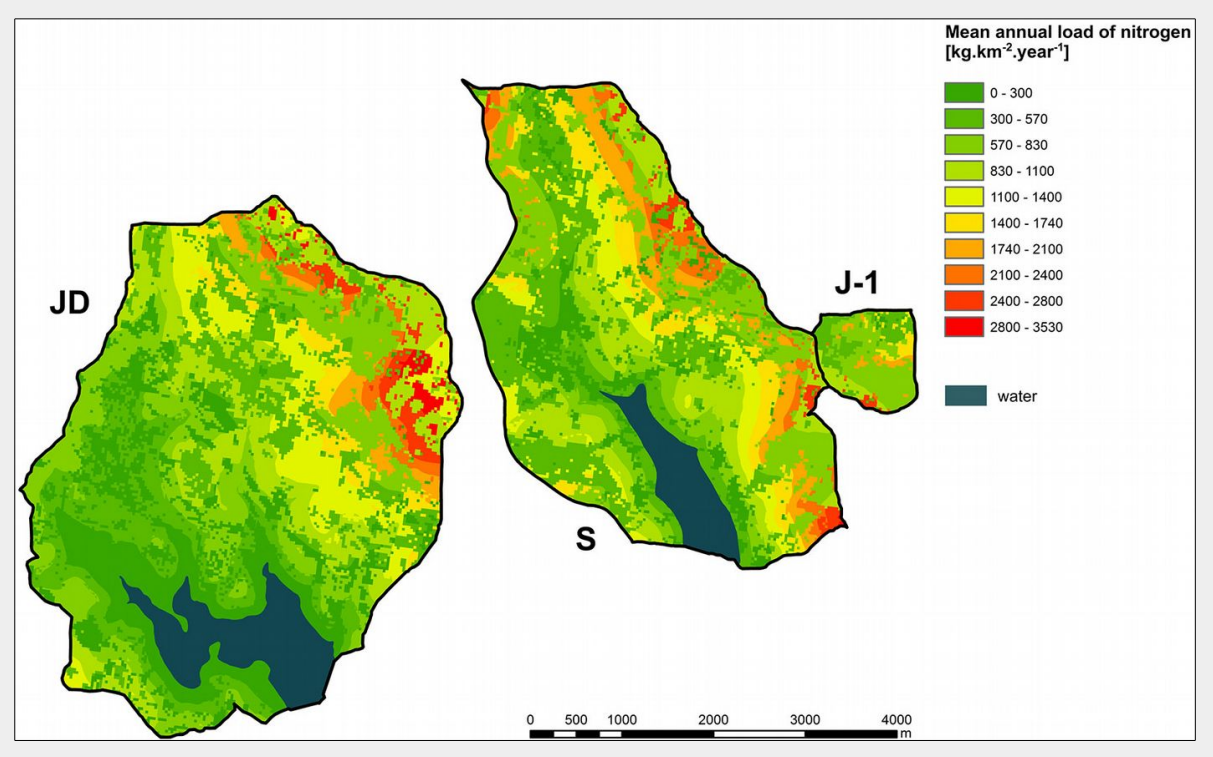




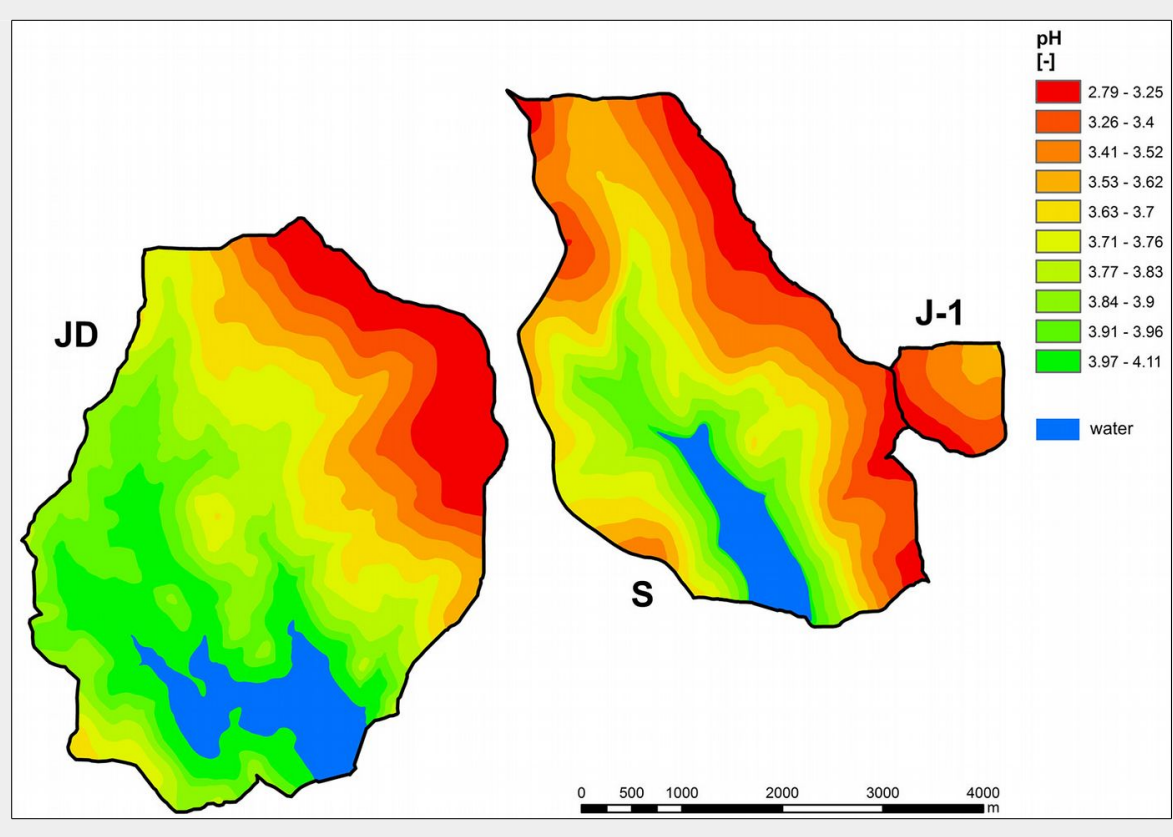

Uncertainties in estimates of atmospheric deposition

The estimated loads of fog water and acidic substances (sulphate, nitrate, ammonia) to the watersheds investigated here are affected by several uncertainties. Generally, in mountainous terrain the accuracy of measured precipitation amounts decreases with increasing wind velocity (Shaw et al. 2010), with significant errors (above $5 \%$ ) when wind velocities are above $2 \mathrm{~m} \mathrm{~s}^{-1}$. For the rain gauges installed in spruce stands (plots 1 and 2), the effect of wind was assumed to be negligible. Generally, errors in chemical analyses are considered to be on the order of $10 \%$. The monthlong storage of rain/fog water in gauges also introduces the risk of error, namely for nitrogen that can be altered by bacterial activity. Nevertheless, Cape et al. (2001) reported negligible changes of $\mathrm{NO}_{3}$ contents in longer sampled rainwater in cold mountain environments, finding that significant errors might occur only in high summer months (July, August), but not exceeding $20 \%$.

The efficiency of passive fog collectors is on the order of $10-20 \%$ of the actual liquid water content in a cloud; the collection efficiency of a single string depends on the size spectrum of the cloud droplets and wind velocities (Schell et al. 1992, Avila et al. 2001). However, our use of passive fog collectors was intended to just indicate the effects of elevation in the upper plain of the Jizera Mountains, assuming comparable wind speeds in the investigated transect (Fig. 1). The collected volumes of fog might also have been affected by the input of surrounding rainfall. However, the passive collectors at the Jizerka transect were protected against inputs of rainfall up to wind speeds of $2 \mathrm{~m} \mathrm{~s}^{-1}$. At higher velocities (based on hourly means) and rainfall intensities above $5 \mathrm{~mm}$ day $^{-1}$, the sampled volumes of fog water were possibly increased by rainfall up to $10 \%$. Considering the collection techniques used, estimates of the canopy structure, and data interpolation, we believe the accuracy of the estimated longterm loads of fog water and acidic substances presented here to be in the range of $\pm 20 \%$. Further research is needed to evaluate the effects of particular meteorological situations (particularly wind speed and direction) on episodic loads of fog drip. However, this study provides initial data for evaluating the effects of possible scenarios of forestry practices on atmospheric loads to the water supply catchments of Josefův Důl and Souš.

\section{Conclusions}

In the Jizera Mountains, the fog water deposition decreases the interception loss in spruce stands (Picea abies) at elevations above $700 \mathrm{~m}$. However, measurable volumes of fog water sampled by passive collectors were detected at elevations above $900 \mathrm{~m}$. Fog drip from the forest canopy was found to increase with elevation and canopy extent. In two mature spruce stands, located at elevations of 745 and $975 \mathrm{~m}$, the observed summer interception losses were $196 \mathrm{~mm}(31 \%)$ and $112 \mathrm{~mm}$ (16\%), respectively, and were significantly affected by fog drip at the higher elevation. The volumes of fog drip sampled by the passive collectors demonstrated the effects of elevation and seasonal variations. In the winter season (NovemberApril), the fog deposition exceeded the summer values (May-October) by $23-50 \%$.

In the catchments of the drinking water reservoirs Josefův Důl and Souš, loads of fog water varied from 88 to $106 \mathrm{~mm}$ (i.e., from $7 \%$ to $8 \%$ of gross precipitation). Therefore, for the mean annual precipitation of $1324 \mathrm{~mm}$ ( $867 \mathrm{~mm}$ runoff), the additional input of fog to the annual water budget could have increased the mean annual water yield from $10 \%$ to $12 \%$. The negative
Fig. 5 - Annual $\mathrm{pH}$ values of fog drip (20112012). effect of fog precipitation on increasing acid deposition in the investigated watersheds was also demonstrated. The mean annual loads of sulphur and nitrogen from fog drip were $658 \mathrm{~kg} \mathrm{~km}^{-2}$ and $216 \mathrm{~kg} \mathrm{~km}^{-2}$ (i.e., $55 \%$ and $48 \%$ of the bulk amounts of sulphur and nitrogen, respectively).

Therefore, in headwater catchments stressed by acidification, the deposition of fog water can enhance the water yield and the recharge of water resources. At the same time, however, it can also affect the quality of surface waters, particularly in environments of a relatively low buffering capacity. Both these effects are related to the elevation and canopy structure, and could therefore be altered by forestry practices modifying the above-ground canopy.

\section{Acknowledgements}

This research was supported by the Earthwatch Institute (Oxford, UK, Project on Mountain Waters of Bohemia), the Grant Agency of the Czech Republic (GAČR 526-09-0567 - CLIMHED), by the Czech Technical University in Prague (SGS 16/140/ $\left.\mathrm{OHK}_{1 / 2 \mathrm{~T}} / 11\right)$, and the Ministry of Education of the Czech Republic (INTER-EXCELLENCE: INTER-COST LTC 17006, 2017).

\section{References}

Andersson F (2005). Coniferous forests. Series "Ecosystems of the world" no. 6, Elsevier, Amsterdam, The Netherlands, pp. 646. [online] URL: http://books.google.com/books?id=YoO8 xKYSJAC

Avila EE, Pereyra RG, Castellano NE, Saunders CPR (2001). Ventilation coefficients for cylindrical collectors growing by riming as a function of the cloud droplet spectra. Atmospheric Research 57: 139-150. - doi: 10.1016/S0169-8095(01) 00067-9

Brechtel HM (1989). Monitoring wet deposition in forest - quantitative and qualitative aspects. In: "Monitoring Air Pollution and Forest Ecosys tem Research: Commission of the European 
Communities, Air Pollution Reports" (Bresser AHM, Mathy P eds). RIVM, Bilthoven, Netherlands, pp. 39-63.

Cape JN, Kirika A, Rowland AP, Wilson DR, Jickells TD, Cornell S (2001). Organic nitrogen in precipitation: real problem or sampling artefact? The Scientific World Journal 1: 230-237. doi: 10.1100/tsw.2001.278

Dawson TE (1998). Fog in the California redwood forest: ecosystem inputs and use by plants. Oecologia 117: 476-485. - doi: 10.1007/s004420 050683

Delleur JW (1989). Atmospheric deposition. International Association of Hydrological Sciences, Wallingford, Oxfordshire, UK, pp. 288.

Golterman H (1969). Methods for chemical analysis of fresh waters. F.A. Davis Company, Philadelphia, PA, USA, pp. 172. [online] URL: http:// eric.ed.gov/?id=ED064114

Hildebrandt A, Eltahir EAB (2008). Using a horizontal precipitation model to investigate the role of turbulent cloud deposition in survival of a seasonal cloud forest in Dhofar. Journal of Geophysical Research 113: 1-11. - doi: 10.1029/200 8JG000727

Holder CD (2003). Fog precipitation in the Sierra de las Minas Biosphere Reserve, Guatemala. Hydrological Processes 17: 2001-2010. - doi: 10.1002/hyp.1224

Holen S, Wright R, Seifert I (2013). Effects of long range transported air pollution (LRTAP) on freshwater ecosystem services. ICP-Waters report 115/2013, NIVA - Norwegian Institute for Water Research, Oslo, Norway, pp. 43. [online] URL: http://brage.bibsys.no/xmlui/handle/1125 o/216428

Igawa M, Matsumura K, Okochi H (2002). High frequency and large deposition of acid fog on high elevation forest. Environmental Science 36: 1-6. - doi: 10.1021/es0105358

Ingwersen JB (1985). Fog drip, water yield, and timber harvesting in the Bull Run municipal watershed, Oregon. Journal of the American Water Resources Association 21: 469-473. - doi: 10.1111/j.1752-1688.1985.tboo158.x

Kim M-G, Lee B-K, Kim H-J (2006). Cloud/fog water chemistry at a high elevation site in South Korea. Journal of Atmospheric Chemistry 55: 13-29. - doi: 10.1007/s10874-005-9004-8

Kopáček J, Procházková L (1993). Semi-micro determination of ammonia in water by the rubazoic acid method. International Journal of Environmental Analytical Chemistry 53: 243248. - doi: 10.1080/03067319308045993

Kreček J, Hořická Z (2006). Forests, air pollution and water quality: influencing health in the headwaters of Central Europe's “Black Triangle”. Unasylva 224: 46-49.

Kreček J, Hořická Z (2010). Recovery of Headwater Catchments and Lakes Affected by the Acid Atmospheric Deposition. In: "Integrated Watershed Management” (Beheim E, Rajwar GS, Haigh M, Křeček J eds). Springer, Dordrecht, Netherlands, pp. 200. - doi: 10.1007/978-90-4813769-5_17

Kreček J, Krčmář V (2015). Landsat imagery applications to identify vegetation recovery from acidification in mountain catchments. Hungarian Geographical Bulletin 64: 121-126. - doi: 10.15 201/hungeobull.64.2.3

Kreček J, Palán L (2015). Effects of fog precipita- tion on water resources and drinking water treatment in the Jizera Mountains. Civil Engineering Journal 24: 1-7. [online] URL: http:// www.civilengineeringjournal.cz/archive/issues/ 2015/2015 2/010-palan_2-2015.pdf

Krečmer V, Fojt V, Kreček J (1979). Fog precipitation and fog drip in forests as an item of water balance in a mountain region. Meteorological Bulletin (Meteorologické zprávy) 32: 78-81. [in Czech]

Krečmer V, Páv B (1982). Methodology to estimate the number of rain gauges under the forest canopy. Journal of Hydrology and Hydromechanics (Vodohospodársky časopis) 479490. [in Czech]

Kroll G, Winkler P (1989). Influence of meteorological parameters on interception of cloud droplets in a coniferous forest. Beitrage zur Physik der Atmosphere 62: 265-274.

Lovett GM, Reiners WA (1986). Canopy structure and cloud water deposition in subalpine coniferous forests. Tellus B 38: 319-327. - doi: 10.3402 /tellusb.v38i5.15140

Lovett GM (1988). A comparison of methods for estimating cloud water deposition to a New Hampshire (USA) subalpine forest. In: "Acid Deposition at High Elevation Sites" (Unsworth $\mathrm{MH}$, Fowler D eds). Springer, Netherlands, pp. 309-320. - doi: 10.1007/978-94-009-3079-7 16

Merilehto K, Kenttämies K, Kämäri J (1988). Surface water acidification in the ECE region: regional acidification, current geographical extent of acidification in lakes, streams and reservoirs in the countries of the ECE region. Nordic Council of Ministers, Copenhagen, Denmark, pp. 156. [online] URL: http://books.google.com/ books?id=E2J5gHEqzvgC

Miller EC, Panek JA, Friedland AJ, Kadlecek J, Mohnen VA (1993). Atmospheric deposition to a high-elevation forest at Whiteface Mountain, New York, USA. Tellus B: Chemical and Physical Meteorology 45: 209-227. - doi: 10.3402/tellusb. v45i3.15725

Mosello R, Barbieri A, Marchetto A (1995). Seasonal variations and trends of atmosphereborne nutriet load to the alpine biosphere and pedosphere. In: "The role of the hydrological cycle in Mountain Ecosystems". University of Zurich, Zurich, Irchel, Switzerland, pp. 17-18.

Motulsky HJ, Searle P (1998). InStat guide to choosing and interpreting statistical tests. GraphPad Software, Inc., San Diego, California, USA, pp. 154.

Pahl S, Winkler P, Arends BG, Kos GPA, Schell D, Facchini MC, Fuzzi S, Gallagher MW, Colvile RN, Choularton TW, Berner A, Kruisz C, Bizjak M, Acker K, Wieprecht W (1997). Vertical gradients of dissolved chemical constituents in evaporating clouds. Atmospheric Environment 31: 25772588. - doi: 10.1016/S1352-2310(96)00285-3

Prošková J, Hůnová I (2006). Assessment methods of fog and low cloud deposition. Meteorological Bulletin (Meteorologické zprávy) 59: 151157.

Ruiz G (2005). Characterization of fog water collection potential at Fort Ord and Glen Deven Ranch near Big Sur. Faculty of Science and Environmental Policy, California State University, Monterey Bay, CA, USA, pp. 27. [online] URL: http://digitalcommons.csumb.edu/caps_thes $/ 5$ 5/
Schell D, Georgii H-W, Maser R, Jaeshke W, Arends BG, Winkler P, Schneider T (1992). Intercomparison of fog water samplers. Tellus $B$ : Chemical and Physical Meteorology 44: 612-631. - doi: 10.3402/tellusb.v44i5.15573

Schemenauer R, Banic CM, Urquizo N (1995). High elevation fog and precipitation chemistry in southern Quebec, Canada. Atmospheric Environment 29: 2235-2252. - doi: 10.1016/1352-2310 (95)00153-P

Schöpp W, Posch M, Mylona S, Johansson M (2003). Long-term development of acid deposition (1880-2030) in sensitive freshwater regions in Europe. Hydrology and Earth System Sciences 7: 436-446. - doi: 10.5194/hess-7-436-2003 Shaw EM, Beven KJ, Chappell NA (2010). Hydrology in practice ( $4^{\text {th }}$ edn). CRC Press, London, UK, pp. 560. [online] URL: http://books.goog le.com/books?id=z1qignvz7YkC

Tolasz R, Baštýřová H (2007). Climate atlas of Czechia. Czech Hydrometeorological Institute, Prague, Czech Republic, pp. 256.

Verhoeven W, Herrmann R, Eiden R, Klemm O (1987). A comparison of the chemical composition of fog and rainwater collected in the Fichtelgebirge, Federal Republic of Germany, and from the South Island of New Zealand. Theoretical and Applied Climatology 38: 210221. - doi: 10.1007/BF00867414

Vogelmann HW (1973). Fog precipitation in the cloud forests of Eastern Mexico. BioScience 23 (2): 96-100. - doi: 10.2307/1296569

Walmsley JL, Schemenauer RS, Bridgman HA (1996). A method for estimating the hydrologic input from fog in mountainous terrain. Journal of Applied Meteorology 35: 2237-2249. - doi: 10.1175/1520-

0450(1996)035<2237:AMFETH>2.0.CO;2

Weathers KC, Lovett GM, Likens GE (1995). Cloud deposition to a spruce forest edge. Atmospheric Environment 29: 665-672. - doi: 10.1016/1352-2310(94)00317-E

Whitman CD (2000). Mountain meteorology: fundamentals and applications. University Press, Oxford, UK, pp. 355.

WHO (2004). Guidelines for drinking water quality ( $3^{\text {rd }}$ edn). World Health Organization, Geneva, Switzerland, pp. 515.

Wrzesinsky T, Klemm O (2000). Summertime fog chemistry at a mountainous site in central Europe. Atmospheric Environment 34: 14871496. - doi: 10.1016/S1352-2310(99)00348-9

\section{Supplementary Material}

Tab. S1 - Coefficients $a, a_{0}$ (eqn. 2) and Pearson's correlation coefficients ( $r$ ) between the deposited fog water and elevation.

Tab. S2 - Coefficients $b, b_{0}$ (eqn. 3) and Pearson's correlation coefficients ( $r$ ) between the deposited acidic substances and elevation.

Tab. S3 - Regression coefficients $k, q$ and Pearson's correlation coefficients ( $r$ ) between $\mathrm{pH}$ of the fog water and elevation.

Link: Palan_2319@supploo1.pdf 